\title{
EVALUATION OF BIOLOGICAL ACTIVE FORMULATES AND STRAINS FOR THE BIOLOGICAL CONTROL OF REPLANT DISEASE IN CITRUS ROOTSTOCKS
}

\author{
Hasan Pinar ${ }^{1, *}$, Suat Kaymak ${ }^{1}$, Aydin Uzun ${ }^{1}$ \\ ${ }^{1}$ Erciyes University, Department of Horticulture, Kayseri, Turkey
}

Current Trends in

Natural Sciences

\begin{abstract}
Knowledge of biotic components of soil "replant disorders" or "replant disease" affecting fruit tree orchards substantially increased in the 1980s, thanks to the in-studies carried out on soil fumigants. In fact, the significant increase of young fruit tree plant growth in fumigated plots in comparison to non-fumigated plots suggested that soil microorganisms play an important role in growth reduction generally classified as "replant disorders". The replant problems affecting all fruit tree crops of high economic value in Europe are strongly related to land degradation problems due to intensive cropping with frequent orchard replants. The combination of the selected resources with low input agro-management practices for controlling soil borne pathogens, such as solarisation, bio-pesticides, soil movement and other available tools etc., should lead to new management options in organic fruit tree orchards. In present study was conducted to determine effect of some product of Bio-formulates in citrus plants which protect from replant disease such as Phytophthora citropthora. Sour orange and Trifliage rootstocks were used and treated ten active ingredient/microorganism for Phytophthora citropthora. All products had positive effect on plant growing, but ISR200 had highest value. This differences can be because of plant material, temperature and product doses.
\end{abstract}

Keywords: bio-formulates, Citrus, rootstocks, replant diseases

\section{INTRODUCTION}

The EU 27 trend of fruit production has decreased from 70 to 60 million tons during the period from 2000 to 2009 (European Fruit Summit, 2010). There are many causes of this yield decline, however one of the main reasons is that of replant disorders due to the eco-functional intensification of growing areas specialising in fruit production occurring in Europe (Savory, 1966; Manici et al., 2003), as wells as in other parts of the world (Mazzola, 1998; van Schoor et al., 2009; Gordon Braun et al., 2010).

Knowledge of biotic components of soil "replant disorders" or "replant disease" affecting fruit tree orchards substantially increased in the 1980s, thanks to the in-studies carried out on soil fumigants. In fact, the significant increase of young fruit tree plant growth in fumigated plots in comparison to non-fumigated plots suggested that soil microorganisms play an important role in growth reduction generally classified as "replant disorders" (Browne et al., 2006). The main agents of replant disease are several soilborne fungal pathogens which can vary according to soil type, cropping practices, crops etc. They are generally defined as "root rot complex". Among the pathogenic agents of the 
root rot complex several species belonging to Cylindrocarpon sp., Pythium sp. Rhizoctonia sp. are known (Savory, 1966; Mazzola, 1998).

Call the replant problems affecting all fruit tree crops of high economic value in Europe are strongly related to land degradation problems due to intensive cropping with frequent orchard replants, this problem is particularly severe in Mediterranean countries where climate (cool humid winters alternating with warm dry summers) lead to a rapid decline in the soil organic matter (SOM) content such as Turkey. The main consequence of progressive SOM depletion is microbial biomass reduction and loss of microbial diversity, with reduction of soil functionality. Microbial diversity, along with microbial biomass, is the best indicator of soil health (Winding and Nielsen, 2002) and represents one of the main components of soil suppressiveness (Garbeva et al., 2004). This can be defined as the potential biological ability of soil to deal with soil-borne pathogens (Borneman and Becker, 2007). Bacterial communities have been widely used as a microbial indicator of soil diversity and soil functioning (Blackwood et al., 2007); however, recently soil fungi have been found to be a good indicator of functioning of agricultural soils (Suzuki et al., 2009).

The occurrence of replant disease is becoming an indicator of a general degraded state of fruit tree orchards. The only effective strategy to control replant disease and crop decline in organic fruit tree orchards is to increase the soil diversity, and consequently, the various microbial processes involved in controlling soil borne pathogens, enhancing root growth and mediating plant nutrition. (Suzuki et al., 2009).

The commercial market of bio-pesticides has expanded significantly in the last five to ten years. Some formulations of fungi and bacteria have been registered as biocontrol agents, but many bioproducts have been marketed as plant growth promoters or plant strengtheners. They include inorganic compounds, composts, organic amendments, homeopathic compounds, microorganisms. These commercial products are not sufficiently regulated by legislation in several countries; in many cases they do not provide the name of biocontrol agents included in the formulation or do not quote the presence of microorganisms; moreover, there is a dearth of published scientific data. As far as the use of these compounds in Europe is concerned, many bio-pesticides come abroad and they contain microorganisms which actually represent alien organisms introduced into our environment. This last aspect has not yet been tackled by legislation, but risks deriving from the introduction of alien organisms should be considered in the medium term. Each of the above mentioned aspects, combined with the partial efficacy of commercial bio-pesticides and the variability of their effectiveness in controlling diseases (Whipps and Davies, 2001), have increased confusion and reduced the interest of producers in the biological control of soil borne pathogens. This could be performed acting on the soil autochthonous microflora, a naturally available resource, with a multi-factorial approach, by working with suitable cropping practices on the numerous biological components of soil suppressiveness.

The combination of the selected resources with low input agro-management practices for controlling soil borne pathogens, such as solarisation, bio-pesticides, soil movement and other available tools etc., should lead to new management options in organic fruit tree orchards. Many of these innovative management options could be easily transferred to other fruit crops such as stone fruits and strawberries, whose yield and quality decline due to the same biological components observed in fruit tree crops.

Phytophthora root rot and gummosis caused by Phytophthora citropthora (Sm. and Sm.) Leonian are major problems in citrus orchards worldwide. This disease was first reported in Turkey in 1958, and it has affected lemon, mandarin, orange, grapefruit and sour orange cultivars (Salih, 1974) 


\section{Current Trends in Natural Sciences}

Vol. 9, Issue 17, pp. 210-215, 2020

https://doi.org/10.47068/ctns.2020.v9i17.026

Current Trends in Natural Sciences (on-line)

ISSN: 2284-953X

Current Trends in Natural Sciences (CD-Rom)

ISSN: 2284-9521

ISSN-L: 2284-9521

ISSN-L: 2284-9521

Survery results in the 1970's the disease incidence in lemon orchards in the provinces of Içel and Adana to be $24 \%$ and $22.4 \%$, respectively. Some cultural practices such as bud unions at soil surface level or less than $15 \mathrm{~cm}$ above soil line, overwatering, poor drainage, soil structure and high clay levels enhance the incidence of the disease. Methods of controlling Phytophthora root rot are generally preventative, e.g., cultural practices and fungicide application to trunk and lower branches. When infection does occur, removal of the infected bark is recommended; however, bark removal diminishes tree performance and fruit yield. This technique is also laborious and uneconomical when attempted on a large scale.

In present study was conducted to determine effect of some product of Bio-Formulates in citrus plants which protect from replant disease such as Phytophthora citropthora.

\section{MATERIALS AND METHODS}

Soils were collected from fields which infected with Phytophthora citropthora. Experiment, Sour orange and Trifliage rootstocks were used and treated ten active ingredient/microorganism for Phytophthora citropthora. We used dose according to recommended company's dosage. Bioformulates were used (Table 1). Sour orange and Trifliage rootstoct plants were transplanted to a 15 liter pot containing to an infested soil mixture. Treatments were applied to plants with 3 replications and every replicate resulted from 6 plants in greenhouse.

Table 1. The List of Product of Bio-Formulates used for Citrus rootstocks.

\begin{tabular}{|c|c|c|}
\hline Name and action & Active ingredient/microorganism & Company or origin \\
\hline Companion & Bacillus subtilis GB03 & Growth products \\
\hline Cropset & $\begin{array}{l}\text { Lactobacillus acidophilus, plant extract, } \mathrm{MnSO} 4 \text {, } \\
\mathrm{FeSO} 4, \mathrm{CuSO} 4\end{array}$ & $\begin{array}{l}\text { Ant Agriculture } \\
\text { (Improcrop EU) }\end{array}$ \\
\hline Isr-2000 & $\begin{array}{l}\text { Lactobacillus acidophilus, plant extract, yeast extract, } \\
\text { benzoic acid }\end{array}$ & $\begin{array}{l}\text { Ant Agriculture } \\
\text { (Improcrop EU) }\end{array}$ \\
\hline Subtilex & Bacillus subtilis MBI 600 & Bioglobal \\
\hline T22 Planter Box & T. harzianum (Rifai Irk Krl-Agz 403) & Hasel Agriculture \\
\hline Tricho plus & T. harzianum & Bioglobal \\
\hline Alexin 95 PS & $\begin{array}{l}\text { Fosfor pentaoksin (P2O5) 52\%, Potasyum Oksit } \\
(\mathrm{K} 2 \mathrm{O}) 42 \%\end{array}$ & Sumitoma \\
\hline Combat Plus & Plant activators & Bioglobal \\
\hline $\begin{array}{l}\text { Endo Roots } \\
\text { Souble }(23,8 \%)\end{array}$ & $\begin{array}{l}\text { Glomus intraradices } \\
\text { Glomus aggregatum } \\
\text { Glomus mosseage } \\
\text { Glomus clarum } \\
\text { Glomus monosporus } \\
\text { Glomus deserticola } \\
\text { Glomus brasilianum } \\
\text { Glomus etunicatum } \\
\text { Gigaspora margarita }\end{array}$ & Bioglobal \\
\hline
\end{tabular}




\section{Current Trends in Natural Sciences}

Vol. 9, Issue 17, pp. 210-215, 2020

https://doi.org/10.47068/ctns.2020.v9i17.026

Current Trends in Natural Sciences (on-line)

ISSN: 2284-953X

Current Trends in Natural Sciences (CD-Rom)

ISSN: 2284-9521

ISSN-L: 2284-9521

ISSN-L: $2284-9521$

Plants were incubated for 4 months in greenhouse, and were kept constantly wet. Pots were subjected them in dripping at $6 \mathrm{~h}$. three times during week. At the end of the growing season plant height $(\mathrm{cm})$, hlant height $(\mathrm{cm})$, root dry weight $(\mathrm{g})$ and shoot dry weight $(\mathrm{g})$ were recorded for all trees in all experiments. At the conclusion of the experiment, results were subjected to analysis of variance according to software programme SAS-JUMP 7.0.

\section{RESULTS AND DISCUSSIONS}

\subsection{Plant Height (cm)}

At the end of the growing season, Plant Height were recorded for all trees in all experiments. The differences between average Plant Height, were found important statistically. And the highest differences were recorded from ISR200(31.4\%). Endo Roots Soluble was the lowest one (3.6\%). Also, T22 Planter Box took second high value (27.6\%) (Table 2).

Table 2. Average Plant Height $(\mathrm{cm})$

\begin{tabular}{|l|l|l|l|l|}
\hline & \multicolumn{4}{|l|}{ Plant Height $(\mathrm{cm})$} \\
\hline & Name and action & Applied & Control & \% Differences \\
\hline 1 & Cropset & 87.0 & 70.5 & $23.4 \mathrm{bc}$ \\
\hline 2 & Compain & 81.5 & 69.7 & $17.0 \mathrm{bc}$ \\
\hline 3 & Subtilex & 70.7 & 66.0 & $7.1 \mathrm{c}$ \\
\hline 4 & T22 Planter Box & 91.5 & 71.7 & $27.7 \mathrm{ac}$ \\
\hline 5 & Combat Plus & 102.2 & 82.7 & $23.6 \mathrm{a}$ \\
\hline 6 & ISR200 & 93.5 & 71.2 & $31.4 \mathrm{ab}$ \\
\hline 7 & Alexin & 78.5 & 78.5 & $0.0 \mathrm{bc}$ \\
\hline 8 & Endo Roots Soluble & 72.3 & 69.8 & $3.6 \mathrm{bc}$ \\
\hline 9 & Endo Roots Soluble & 82.8 & 78.3 & $5.7 \mathrm{ac}$ \\
\cline { 2 - 5 } & LSD(5\%) & 12.06 & & \\
\hline
\end{tabular}

There was significant differences in the same column between the averages $(\mathrm{P} \leq 0.05)$,

\subsection{Trunk Diameter}

Avarage trunk diameter measured at end of the growing season and showed Table 3. As obtained results from Product of Bio-Formulates, ISR200 was highest difference value (15.8\%) with regard to trunk diameter. But Alexin got lowest value $(0.6 \%)$.

Table 3. Average Trunk Diameter ( $\mathrm{mm})$

\begin{tabular}{|c|c|c|c|c|}
\hline & & \multicolumn{3}{|c|}{ Trunk Diameter $(\mathrm{mm})$} \\
\hline & Name and action & Applied & Control & $\%$ Differences \\
\hline 1 & Cropset & 10.0 & 9.8 & $1.9 \mathrm{bc}$ \\
\hline 2 & Compain & 10.1 & 9.7 & $4.2 \mathrm{bc}$ \\
\hline 3 & Subtilex & 9.9 & 9.8 & $1.4 \mathrm{c}$ \\
\hline 4 & T22 Planter Box & 11.6 & 10.2 & $14.0 \mathrm{ac}$ \\
\hline 5 & Combat Plus & 12.0 & 10.4 & $15.4 \mathrm{ab}$ \\
\hline 6 & ISR200 & 11.6 & 10.0 & $15.8 \mathrm{ac}$ \\
\hline 7 & Alexin & 10.4 & 10.4 & $0.6 \mathrm{ac}$ \\
\hline 8 & Endo Roots Soluble & 11.2 & 9.6 & $16.5 \mathrm{ac}$ \\
\hline 9 & Endo Roots Soluble & 12.1 & 11.0 & $9.5 \mathrm{a}$ \\
\hline & $\operatorname{LSD}(5 \%)$ & 1.25 & & \\
\hline
\end{tabular}

There was significant differences in the same column between the averages $(\mathrm{P} \leq 0.05)$, 


\section{Current Trends in Natural Sciences}

Vol. 9, Issue 17, pp. 210-215, 2020

https://doi.org/10.47068/ctns.2020.v9i17.026

Current Trends in Natural Sciences (on-line)

ISSN: 2284-953X

Current Trends in Natural Sciences (CD-Rom)

ISSN: 2284-9521

ISSN-L: 2284-9521

ISSN-L: 2284-9521

\subsection{Root Dry Weight}

Avarage Root Dry Weight calculated at end of the growing season after dried at $65 \mathrm{C}$ in etuve and showed at Table 4. ISR200 had the highest difference when compared with control plants with $34.7 \%$ difference value. Compain had the lowest difference value $(0.5 \%)$ with regard to root dry matter content.

Table 4. Root Dry Weight $(g)$

\begin{tabular}{|l|l|l|l|l|}
\hline & & \multicolumn{4}{|l|}{ Root Dry Weight (g) } \\
\hline & Name and action & Applied & Control & \% Differences \\
\hline 1 & Cropset & 44.2 & 41.7 & $6.0 \mathrm{ab}$ \\
\hline 2 & Compain & 33.8 & 33.7 & $0.5 \mathrm{~b}$ \\
\hline 3 & Subtilex & 35.8 & 34.2 & $4.9 \mathrm{ab}$ \\
\hline 4 & T22 Planter Box & 43.0 & 33.3 & $29.0 \mathrm{ab}$ \\
\hline 5 & Combat Plus & 58.3 & 41.0 & $42.3 \mathrm{a}$ \\
\hline 6 & ISR200 & 55.0 & 40.8 & $34.7 \mathrm{a}$ \\
\hline 7 & Alexin & 44.0 & 35.8 & $22.8 \mathrm{ab}$ \\
\hline 8 & Endo Roots Soluble & 52.5 & 40.0 & $31.3 \mathrm{ab}$ \\
\hline 9 & Endo Roots Soluble & 48.3 & 40.0 & $20.8 \mathrm{ab}$ \\
\cline { 2 - 5 } & LSD(5\%) & 12.85 & & \\
\hline
\end{tabular}

There was significant differences in the same column between the averages $(\mathrm{P} \leq 0.05)$,

\subsection{Shoot Dry Weight}

Shoot dry matter content calculated after harvest and dried under $65 \mathrm{C}$ in etuve. As obtained result, ISR200 had the highest difference value (60\%), but T22 Planter Box had the lowest value (4.7\%) (Table 5).

Table 5. Shoot Dry Weight (g)

\begin{tabular}{|l|l|l|l|l|}
\hline & \multicolumn{4}{|c|}{ Shoot Dry Weight $(\mathrm{g})$} \\
\hline & Name and action & Applied & Control & \% Differences \\
\hline 1 & Cropset & 51.7 & 40.0 & $29.2 \mathrm{~b}$ \\
\hline 2 & Compain & 43.8 & 38.8 & $13.1 \mathrm{~b}$ \\
\hline 3 & Subtilex & 43.3 & 38.3 & $13.0 \mathrm{~b}$ \\
\hline 4 & T22 Planter Box & 45.0 & 43.0 & $4.7 \mathrm{~b}$ \\
\hline 5 & Combat Plus & 64.2 & 57.0 & $12.6 \mathrm{c}$ \\
\hline 6 & ISR200 & 60.0 & 37.5 & $60.0 \mathrm{a}$ \\
\hline 7 & Alexin & 51.0 & 40.8 & $24.9 \mathrm{~b}$ \\
\hline 8 & Endo Roots Soluble & 50.8 & 37.5 & $35.6 \mathrm{~b}$ \\
\hline 9 & Endo Roots Soluble & 33.3 & 20.8 & $60.0 \mathrm{a}$ \\
\cline { 2 - 5 } & LSD(5\%) & 10.86 & & \\
\hline
\end{tabular}

There was significant differences in the same column between the averages $(\mathrm{P} \leq 0.05)$

\section{CONCLUSIONS}

Phytophthora root rot and gummosis caused by Phytophthora citropthora (Sm. and Sm.) Leonian are major problems in citrus orchards worldwide. This problem formed as replant disease at citrus production at mediterranean region. There are lots of pesticide aplication to protect from Phytophthora citropthora. But when pesticides were applied, soils and envioriment under thread. 
Best solution for this problem is bio formulates. In present study, effect of nine different bio formulate which have sale by different companies were determined. All product had positive effect on plant growing, but ISR200 had highest value. This differences can be because of plant material, temperature and product doses.

\section{ACKNOWLEDGEMENTS}

Present study supported by EU CORE ORGANIC II Project

\section{REFERENCES}

Savory, B.M. (1966). Specific replant diseases causing root necrosis and growth depression in perennial fruit and plantation crops. Research Rev. Commonw. Bur. Horth. Pl. Crops $64 \mathrm{pp}$

Manici, L.M., Ciavatta, C., Kelderer, M., Erschbaumer, G. (2003) Replant problems in South Tyrol: role of fungal pathogens and microbial populations in conventional and organic apple orchards. Plant \& Soil 256, 315-324

Mazzola, M. (1998) Elucidation of the microbial complex having a causal role in the development of apple replant disease in Washington. Phytopathology 98, 930-938.

van Schoor, L., S. Denman, Cook, N.C. (2009). Characterization of apple replant disease under South African conditions and potential biological management strategies. Sci. Hort. 119, 153

Gordon Braun, P., Fuller K.D., McRae, K., Sherry, A.E. (2010) Fillmore Response of 'Honeycrisp ' Apple Trees to Combinations of Pre-plant Fumigation, Deep Ripping, and Hog Manure Compost Incorporation in a Soil with Replant Disease HortScience 45, 1702-1707

Browne, G.T., Connell, J.H., Schneider, S.M. (2006) Almond replant disease and its management with alternative preplant soil fumigation treatments and rootstocks. Plant Disease 90, 869-876.

Mazzola M. (1998) Elucidation of the microbial complex having a causal role in the development of apple replant disease in Washington. Phytopathology 98, 930-938.

Winding, A., Nielsen, M. N.(2002) Microorganisms as Indicators of Soil Health. Techn. Rep n.388. 82 pp.

Garbeva P., van Veen J.A., van Elsas J.D. (2004) Microbial diversity in soil: selection of microbial populations by plant and soil type and implications for disease suppressiveness. Annual Review of Phytopathology, 42, 243-70.

Borneman, J., Becker, J.O. (2007) Identifying Microorganisms Involved in Specific Pathogen Suppression in Soil. Ann. Rev. Phytopath. 45, 153-172.

Blackwood, C.B., Hudleston, D., Zak, D.R., Buyer, J. S. (2007). Interpreting Ecological Diversity Indices Applied to Terminal Restriction Fragment Length Polymorphism Data: Insights from Simulated Microbial Communities. Appl. Environ. Microbiol. 73, 5276-5283

Suzuki, C., Nagaoka, K.., Shimada, A., Takenaka, M. (2009) Bacterial communities are more dependent on soil type than fertilizer type, but the reverse is true for fungal communities. Soil Sci. Pl Nutrition 55, 80-90

Manici, L. M., Caputo, F. (2010). Soil fungal communities as indicators for replanting new peach orchards in intensively cultivated areas. European journal of agronomy, 33(3), 188-196.

Cook, R., Rayner, A.D.M. (1984) Ecology of Saprotrophic Fungi. Longman, London, New York, 415 pp. European Fruit Summit 2th ed. 2010 Cesena, Italy

Whipps, J.M., Davies, K.G. (2001) Success in biological control of plant pathogens and nematodes by microorganisms, status and prospects. In Butt et al. Fungal as biological agents progress, problems and potential. 2001. 1-8. $C A B$ International New York. 